\title{
Serum creatine kinase activity in untreated primary hypothyroid children
}

\author{
U K Jayantha ${ }^{1}$ \\ Sri Lanka Journal of Child Health, 2004; 33: 106-7
}

(Key words: Creatine kinase, primary hypothyroidism, Kocher-Debre-Semelaigne syndrome)

\begin{abstract}
Objectives To determine association between primary hypothyroidism and serum creatine kinase (CK) activity in children.
\end{abstract}

Design and Setting Prospective study of patients seen at university paediatric unit, Galle for a period of 4 years starting from January 1998.

Method Primary hypothyroidism was confirmed by presence of elevated serum thyroid stimulating hormone and low thyroxine for age. All newly diagnosed patients with primary hypothyroidism were tested for serum CK activity. Levels were compared with serum CK activity in normal euthyroid children. Serum CK levels were repeated 6 weeks after starting thyroxine therapy.

Results 19 children presented with primary hypothyroidism during study period. All had elevated serum CK levels. 2 patients showed clinical evidence of muscular hypertrophy. There were 7 neonates with congenital hypothyroidism.

Conclusions: Elevated levels of CK activity were seen in all children with untreated primary hypothyroidism in this series. CK activity became normal 4-6 weeks after starting therapy. Hence elevated serum $\mathrm{CK}$ could be used as an indicator for diagnosis of untreated hypothyroidism or to assess adequacy of therapy in primary hypothyroidism.

\section{Introduction}

Myopathy is thought to be a rare manifestation in children with congenital hypothyroidism. Muscular hypertrophy in hypothyroid children is known as Kocher-Debre-Semelaigne syndrome. Muscle involvement is generalized but most prominent in the calf muscles. Muscle strength is usually normal or decreased. With thyroxine therapy muscle mass returns to normal ${ }^{1}$. Serum creatine kinase (CK) levels can increase up to 12 fold in this condition ${ }^{2}$.

${ }^{1}$ Senior Lecturer in Paediatrics, Department of Paediatrics, Faculty of Medicine, Galle.
Myopathy in congenital hypothyroidism leads to type 1 or type 2 fibre hypertrophy. Myofibre necrosis and regeneration is also seen in this condition.

\section{Objectives}

To determine association between primary hypothyroidism and serum CK activity in children.

\section{Design}

Prospective study.

\section{Setting}

Patients were seen at university paediatric unit, Galle for a period of 4 years starting from January 1998.

Table 1

Serum TSH, thyroxine and creatine kinase levels

\begin{tabular}{|l|l|l|l|l|l|}
\hline No & $\begin{array}{l}\text { Age } \\
\text { (months) }\end{array}$ & $\begin{array}{l}\text { Sex } \\
\text { SSH } \\
(\mu u / m l)\end{array}$ & $\begin{array}{l}\text { Serum } \\
\text { thyroxine } \\
\mu g / d l\end{array}$ & $\begin{array}{l}\text { Serum } \\
\text { (U/L) }\end{array}$ \\
\hline 1 & 01 & $\mathrm{~F}$ & $>75$ & $<1$ & 640.3 \\
\hline 2 & 01 & $\mathrm{~F}$ & $>100$ & $<20$ & 852 \\
\hline 3 & 15 & $\mathrm{~F}$ & 75 & 1 & 1073.4 \\
\hline 4 & 84 & $\mathrm{~F}$ & $>60$ & $<1$ & 1980 \\
\hline 5 & 60 & $\mathrm{~F}$ & 37.6 & $<1$ & 340 \\
\hline 6 & 1 & $\mathrm{~F}$ & $>75$ & $<1$ & 640.3 \\
\hline 7 & 84 & $\mathrm{~F}$ & $>75$ & 0.2 & 246 \\
\hline 8 & 1 & $\mathrm{~F}$ & 10 & 0.2 & 267 \\
\hline 9 & 96 & $\mathrm{M}$ & $>75$ & 0.1 & 560 \\
\hline 10 & 20 & $\mathrm{M}$ & 75 & 4.6 & 449 \\
\hline 11 & 1 & $\mathrm{~F}$ & 8 & 1.2 & 211 \\
\hline 12 & 1 & $\mathrm{~F}$ & 10 & $<20$ & 746 \\
\hline 13 & 15 & $\mathrm{~F}$ & 73 & 13.7 & 369 \\
\hline 14 & 72 & $\mathrm{M}$ & 45 & 3.3 & 220 \\
\hline 15 & 108 & $\mathrm{~F}$ & $>50$ & 0.3 & 213 \\
\hline 16 & 15 & $\mathrm{M}$ & $>60$ & 6 & 240 \\
\hline 17 & 20 & $\mathrm{M}$ & $>20$ & 20 & 240 \\
\hline 18 & 1 & $\mathrm{M}$ & 39.9 & 0.03 & 293 \\
\hline 19 & 3 & $\mathrm{~F}$ & $>60$ & 0.3 & 680 \\
\hline & & & & & \\
\hline
\end{tabular}

(Received 17 May 2004) 


\section{Method}

Primary hypothyroidism was confirmed by presence of elevated serum thyroid stimulating hormone (TSH) and low thyroxine for age. All newly diagnosed patients with primary hypothyroidism were tested for serum CK activity. CK levels were reestimated 4-6 weeks after starting thyroxine. Consent was obtained from the parents.

\section{Results}

19 children ( 6 boys, 13 girls) presented with primary hypothyroidism during the study period. Their ages ranged from 1 month to 9 years. There were 7 neonates with congenital hypothyroidism. All children with primary hypothyroidism had elevated serum CK activity.

2 children ( 7 year old girl and 8 year old boy) showed clinical evidence of muscular hypertrophy. Their muscle power ranged from grade 3-4 at different muscle groups.

Mean serum CK activity in hypothyroid children was 533.9 U/L (SD 419.8). Mean serum CK activity in neonates with congenital hypothyroidism was 521.3 $\mathrm{U} / \mathrm{L}$ (SD 258.6). Mean serum CK activity in euthyroid children (control group of 30) was 96.7 $\mathrm{U} / \mathrm{L}$ (SD 45.03). The reference value of serum $\mathrm{CK}$ in children is $50-195 \mathrm{U} / \mathrm{L}$.

\section{Discussion}

Myopathy in untreated congenital hypothyroidism is called Kocher-Debre-Semelaigne Syndrome. This is a rare condition associated with generalized muscular hypertrophy especially calf muscle, weakness of muscles and elevated serum CK activity. Serum CK activity can increase up to 12 fold in this condition ${ }^{2}$.
In this study there were 2 children with KocherDebre-Semelaigne syndrome. They rapidly responded clinically to thyroxine therapy and serum CK levels came back to normal within 4 weeks. All the other hypothyroid children also had elevated serum CK activity. Their mean serum CK value was 553.9 U/L (control 96.7 U/L). Serum CK activity became normal within 4 weeks of thyroxine therapy.

\section{Conclusions}

Results of our study show that all children with untreated hypothyroidism had elevated CK levels. Hence we conclude that elevated serum CK levels are constant in untreated hypothyroidism and this can be used as a diagnostic aid as well as for assessment of adequacy of thyroxine therapy.

\section{References}

1. Najjar S S. Muscular hypertrophy in hypothyroid children: The Kocher-Debre-Semelaigne syndrome. Journal of Pediatrics 1974; 85(2): 236-9.

2. Nancy J H, Lillian H L, George T B. Acquired hypothyroidism with muscular hypertrophy and precocious testicular enlargement. Journal of Pediatrics 1974; 85(2): 233-6. 
